\title{
24
}

PROJECT MUSE

\section{A Chariot Between Two Armies: A Perfectionist Reading of the} Bhagavadgitā

University of Hawaii

Press

Paul Deb

Philosophy East and West, Early Release Articles, (Article)

Published by University of Hawai'i Press

This is a preprint article. When the final version of this article launches, this URL will be automatically redirected.

$\Rightarrow$ For additional information about this preprint article https://muse.jhu.edu/article/765014/summary 


\section{A Chariot Between Two Armies:}

\section{A Perfectionist Reading of the Bhagavadgit $\bar{a}$}

\section{Paul Deb}

Department of Philosophy, University of East Anglia paul.deb@uea.ac.uk

In the Indian epic Mahabharata, in the particular part of it called Bhagavadgita, on the eve of the battle that is the central episode of the epic, the invincible warrior, Arjuna, expresses his profound doubts about leading the fight which will result in so much killing. He is told by his adviser, Krishna, that he, Arjuna, must give priority to his duty, that is, to fight, irrespective of the consequences. That famous debate is often interpreted as one about deontology versus consequentialism, with Krishna, the deontologist, urging Arjuna to do his duty, while Arjuna, the alleged consequentialist, worries about the terrible consequences of the war.

Amartya Sen, The Idea of Justice ${ }^{1}$

Given the dominance of the struggle between teleological and deontological doctrines (primarily represented by versions of utilitarianism and Kantianism), in the field of modern Western moral philosophy, it is perhaps hardly surprising that when philosophers working in that tradition attempt to interpret the ethical significance of classic texts of non-Western traditions such as the Bhagavadgit $\bar{a},{ }^{2}$ they should do so in ways that reflect that dominance: articulating its central issue or dilemma in the light of these theories, and understanding its purported commitments and resolution as expressing a recognisable inflection of one or other of these doctrines. In so doing of course, what they are at risk of occluding are not only aspects or features of the text which may not readily conform to the lineaments of such 
reigning theories, but the opportunity it may present to take an independent or critical perspective upon them - not least, upon the idea of the kingdom of moral enquiry as essentially divided between two such opposing forces in the first place. ${ }^{3}$

At the same time however, it is hard to understand how it might be possible to approach this (or any other) text without some such orienting interpretative assumptions and theories; for without them we would not even know what it was we were trying to interpret. This familiar hermeneutic point suggests that what counts is not attempting (per impossibile) to approach a text free of preconceptions, but to evaluate their fruitfulness in each case, and to do so in terms which the text itself makes available. It also suggests that approaching a text with a different basic orientation or set of concerns may serve to illuminate aspects of it which prevailing interpretations may have otherwise failed to acknowledge or disclose.

It is this approach that I will take here. For while in the course of my discussion I will (mainly implicitly) acknowledge the presence of both consequentialist and deontological aspects of the Gittā, I do not mean ultimately to take sides with either; and in so far as my interpretation refuses such alignments, it thus cannot be understood to be attempting to make yet another contribution to the debate on the moral or ethical nature of the Gitta in those terms (indeed, as a result, it is an open question whether my reading can be taken, straightforwardly at least, to be a moral one at all). Instead, I want in this paper to focus on a conception of moral or spiritual thinking that can be understood both to cut across and underlie the territories which those theories occupy - that developed by Stanley Cavell in his work on Emerson, ${ }^{4}$ which he labels 'Emersonian Moral Perfectionism' .

\section{Moral Perfectionism}

It is crucial to Cavell's understanding of perfectionism that he does not see it as a species of moral theory similar to, and so in competition with, the dominant varieties of teleological or 
deontological doctrine. Rather he sees it as a tradition or dimension of the moral life embodied and developed in a diverse set of texts spanning the range of Western culture that any theory of that life must accommodate or presuppose (something evinced by his identification of deep strains of perfectionism in the views of key representatives of such theories, like Mill and Kant, and by my acknowledgement here of such theories in the Gìtā): [T] he moral outlook (or dimension) of moral perfectionism, one which, in contrast to an emphasis on calculating the good or bad of a course of action, or establishing the morality of a principle announcing the right or wrong of a course of action focuses instead on the worth of a way of life, of my way of life, which has come to a crossroads demanding self-questioning, a pause or crisis in which I must assess something that has been characterised as my being true to myself, something the romantics (explicitly including Emerson) articulated as the imperative to become the one I am. (Cavell, 2004, p. 49)

In other words, for Cavell, as it were before our more familiar moral concerns with the good and the right in moral reasoning - prior to the self's judgements on, and duties towards others - there arises the issue of the formation of moral consciousness as such; of whether and how the moral agent can be said to have a self (and a way of life expressive of that self) from which such concerns might genuinely emerge and to which they can apply.

It is this issue of one's possession or relation to one's self, that Cavell understands as the rightful province of moral perfectionism; and which he sees as underlying its founding myth or vision: an idea of being true to oneself, or to the humanity in oneself - of the soul as on an upward or onward journey that begins by finding oneself spiritually disorientated, lost to the world, and requiring a refusal of the current condition of society in the name of some further or higher, more cultured or cultivated, state of society and the self (Cavell, 1990, p. 1). This myth thus suggests a conception of both the human soul and its society as inherently 
divided or doubled, as ineradicably split into what Cavell, following Emerson, describes as a presently attained state and a further or future unattained, but attainable state. On this view, there is therefore no given condition of the self and society that is ultimately final, no state which, when attained, that lacks a yet further, potentially attainable, neighbour. In this sense, Emersonian perfectionism sets its face against any idea of human perfectibility.

Cavell does however see it as implying a provisional or transient perfection. For each attained state of the self constitutes a world within which its desires are manifested and within which they may be satisfied. Each stage or step on the soul's journey is thus in a certain sense perfect: the ideally complete place for the self to enact its presently attained existence. And for Cavell, it is the settled attractions of the self's presently attained state that lead to the species of spiritual disorientation with which perfectionism is concerned. In such a condition, the self's desires become attached to, or fixated upon, its attained state - often by a conformity to prevailing modes of thought and life - to the extent that its unattained but attainable state is effectively negated or eclipsed. This fixation or conformity thereby fails to acknowledge the essential doubleness of the human self, and so fully the humanity in oneself, by withholding from the self the possibility of continuing on its journey, of spiritual progress.

Consequently, anyone in this condition experiences a form of spiritual crisis which they will be unable to diagnose or overcome on their own - such an individual will need the assistance of another to help her to avert conformity and reorient herself. Drawing on Emerson's notion of representativeness, Cavell understands this interlocutor as revealing to the disorientated individual the reliance upon her attained state to which she has presently succumbed by exemplifying or representing to her a further or future attainable state of herself (so effectively taking the place of, or standing for, her presently repressed unattained self). In so doing, the interlocutor aims to attract the disorientated to decline the current condition of society with which she has become fixated, and instead incline towards the one 
which the interlocutor represents - thereby shifting the balance of reliance from her attained to her attainable self, and so reorienting or transforming herself. In short, the interlocutor aims to resuscitate her companion's self-reliance or autonomy.

For Cavell, these features of the founding perfectionist myth are variously inflected or interpreted by the different texts in which they find expression (the notion of the journey, for example, being variously portrayed as a stairway, ladder or path). But he nonetheless identifies Plato's Republic as providing its most extended and systematic philosophical account; and does so in terms which make a comparison with the Gìtā even more suggestive. For there the myth is expressed in terms of a mode of conversation between two friends: where the younger is understood as the one experiencing a form of spiritual disorientation or crisis and the older is understood as the one who leads the younger to overcome that condition. In other words, the Republic (and I would like to say the Gittā) conceives of perfectionism in terms of a process of education or edification of a younger friend by an older; in the form of a relationship between a figure of a student or apprentice, and that of a teacher or master.

The Bhagavadgìtā is of course a dialogue between such younger and older friends Arjuna (third of the royal Pāṇdava brothers) and Kṛṣna his adviser and charioteer (in truth an incarnation or avatar of the god Vișnu). Set on the eve of the Pāndavas' great battle with their cousins the Kauravas over the right of succession, the text famously begins with Arjuna ordering Krṣna to drive his chariot into the centre of the battlefield at Kurukșetra, from where - stationed between the two armies - Arjuna sees that the enemy he faces is composed of his relatives, teachers and former friends, and so refuses to fight and sinks into despair. Putting aside his natural aversion to waging war against family and friends, Arjuna offers reasons against fighting which stem from what he believes would be the disastrous consequences of his actions and which rest ultimately on an appeal to the notion of dharma. Indeed, as the first 
line of the Gitta declares, the battle which it details is to be fought not only on the field at Kurukșetra, but on the 'field of dharma' (dharmakșetra): in short, Arjuna's true battle is a dharmic one. Accordingly, I want to begin my reading of the Gìtā by suggesting how the dharmic nature of Arjuna's despair is essentially related to a recognisably perfectionist demand that he be true to himself - that the crisis which he experiences is one that leads him profoundly to question the nature of his (true) identity.

\section{Dharma and Disorientation}

Derived from the Sanskrit root ' $d h r$ ' meaning 'to uphold' or 'support', in the early, pre-epic phase of religious life in India characterised by the Veda, dharma - in its root form and that of the related noun 'dharman' - was identified with acts of sacrifice; in particular, with the primeval, divine cosmogonic acts which distinguished heaven from earth and upheld the distinctive natures of things in the world. These divine acts of sacrificial cosmogony established the first ritual statutes or laws and served as a model or archetype for their human reproduction in the form of ritual sacrifice. Adherence to such ritual laws thus expressed a concern with maintaining or upholding the cosmos and so with distinguishing, and thereby acknowledging, the particular identity of every entity which it contained. As the Vedic period progressed 'dharman' increasingly became replaced by the more abstract 'dharma' marking a change from the denoting of the event or action of 'upholding' to its subsequent result or effect; i.e., the established order. With this change of emphasis the significance of dharma began to extend beyond cosmogonic and ritual contexts into the realms of social and ethical norms, and in the later, post-Vedic works it is these meanings that come to predominate.

Dharma becomes the moral law embodied in the familiar varnāśramadharma; the order of the four estates or classes (varnas) of society and the four stages of life (āśramas) that determines the roles and duties incumbent upon an individual; governing not only one's 
occupation, but nearly all aspects of one's experience: marital status, domestic habits, right conduct, relations to others, and involvement with regard to religious ceremonies. And in observing one's station according to varṇāśramadharma (i.e., doing one's duty) one was thereby understood to be contributing to the sustaining of the world and the proper upholding of its fundamental divisions and orders. In this sense, the emphasis of varnāśramadharma could still be viewed as ritualistic, but with the qualification that what now counted as ritual had itself grown beyond strictly ritualistic contexts to include other spheres of social life.

The picture of society as constituted by individuals occupying specific positions within a well-defined and highly determinate system of roles and statuses is of course not alien to the Western tradition, having been available since its inception (Plato's ideal state being perhaps the most well-known early example). More recently, Alasdair MacIntyre (1985, chap. 10) has provided an account of the nature of morality within what he calls 'heroic societies' (exemplified for him by Homeric, ancient Irish and early Icelandic cultures) which bears an affinity with the varnāśramadharma found in the Hindu tradition. As MacIntyre suggests, for individuals living in such heroic societies questions concerning how one ought to behave (one's moral code) flow immediately from the nature of one's specific position within society; from a conception of the tasks and duties specific to one's role (as a soldier, priest, etc.) to one's acting in accordance with that role (to act as a soldier or priest ought, etc.). Indeed, for such heroic individuals the full spectrum of moral considerations one may engage in - whether one ought to act in a certain way or refrain from doing so, the worth of one's actions, how one may treat and regard others (themselves understood as occupants of specific social roles) - all depend on who one is. Thus, in so far as right action in heroic societies is a function of one's identity, and that identity is in turn defined by an individual's social role, MacIntyre suggests that in such societies morality and social structure amount to the same thing; as he puts it, 'evaluative questions are questions of social fact' (1985, p. 123). 
In the present context, both could be said to be aspects of dharma, the moral, social and cosmic law.

Furthermore, since in heroic society an individual's identity is determined by the activities, cares and commitments which her role requires or sanctions - that in effect she is what she does - the idea of rejecting or distancing herself from that role would amount to the sloughing off of her identity. And in so far as that identity provided an evaluative framework by which the meaning or significance of the objects of the individual's experience were organised - of how things in the world were related to someone of her position - such a shedding of her identity would amount to the abandoning of the world. Accordingly, any individual who found themselves in such a situation would be in the grip of an appalling identity crisis, ignorant of where she stood on a variety of fundamental issues, and thus unable to know how to act. In effect, she would no longer know who she was.

It would seem that it is in precisely such a crisis that Arjuna finds himself. As Kṛ̣nạa reminds him, varnāśramadharma dictates that as a kṣatriya, or warrior, it is Arjuna's duty or dharma to fight in the battle at Kurukșetra. At the same time however, Arjuna believes that waging war against his cousins would violate the ancient dharma of the family (kuladharma) with disastrous consequences. Arjuna is therefore caught in a moral or dharmic conflict: he contravenes a moral code whether he wages war or fails to do so. Consequently, with no clear guidance as to how to proceed he finds himself at a crossroads, exhibiting the spiritual disorientation or confusion to which perfectionist thinkers are so sensitive. By refusing to conform to the dharma incumbent upon him as a kșatriya, he transgresses the law which underpins that and all other roles, and which ultimately sustains the world: in short, by questioning his role as a kṣatriya he questions everything. Unable therefore to go on in the way dictated by dharma, the world becomes lost to Arjuna. His grip on it slipping away like the bow Gāṇ̣īiva from his hand. 
It thus falls to Arjuna's older friend, Kṛṣna, to reorient him, to lead him back to the world and himself. But it is important to recognise that Kṛṣna not only responds to Arjuna's crisis, he precipitated it as well. As an incarnation of Viṣnu, he has long since foretold of the war between the Kauravas and Pāṇavas; he has already decided its outcome, and who on the battlefield shall die (Arjuna's attempt to spare his enemies is thus in vain - to Kṛṣna they are already dead). Moreover, Kṛ̣nạ’s omniscience suggests that the events of the Gìtā itself must also have been preordained; that Arjuna's refusal to fight on the eve of battle, and Kṛ̣na's subsequent teachings, are part of a divine plan, with Arjuna fated from birth merely to be the occasion or instrument for its execution (BG 11.33: p. 117). And we might see this passive or necessitarian aspect of Arjuna's predicament as underwritten by the mood of despair which accompanies it. For a mood is not the result of a decision or action; but rather something which assails one from outside oneself, something that one suffers.

But Arjuna's suffering is not without a point or purpose. For in perfectionist terms it is necessary first for the older friend or teacher to precipitate or bring his pupil into crisis, so that the pupil sees his life as in some way deficient or misguided (for someone so afflicted could not come to such a conclusion unaided), in order that he then may receive the teaching necessary to redeem himself. And Kṛșna’s plan has precisely this effect, for in the midst of his confusion Arjuna turns to his friend pleading for instruction: 'My nature afflicted with the vice of despair / My mind confused over what is the Law / ...Pray guide me, your student who asks for your help!' (BG 2.7: p. 75).

\section{Karma and Culture}

Appropriately, given that the decision facing Arjuna is whether he ought to act on the battlefield or refuse to do so, the heart of the teaching that Kṛ̣na subsequently provides concerns the concept of action. In so doing, he offers a radical reworking of the orthodox 
understanding of action which had prevailed since the time of the Upanisads. And it is in the course of this account that the Gìtà provides its own version of the perfectionist conception of the soul and its society as inherently divided or doubled.

Traditionally, the concept of action had been closely allied with the doctrine of rebirth. The actions or works (karman) which an individual performed during her life were believed necessarily to amass merit (punya) or demerit (pāpa) depending on their moral worth or character; the relative accumulation of which served to determine the nature or condition of her subsequent rebirth (as an insect, animal, or if as a human being, within what class (varna $)$ ). In this way, although an individual's good and bad deeds may not have found recompense in this life, they were guaranteed to do so in the next. And with each new life new schedules of debt and credit were produced by one's acts, necessitating a further life in which they could be collected. This is the law of action or (more famously) karma which binds human beings to samsāra, the seemingly endless cycle of birth and rebirth - a recognisably perfectionist picture of the human soul as at any point ineluctably partial or incomplete, as split between what is has been and what it could become, as ineradicable journeying between selves (just as one might discard worn-out clothes and put on new ones (BG 2.22: p. 75)).

However, there is a key variation in this version of the perfectionist myth: for unlike Cavell's emphasis on the unending nature of this journey, here just such an end is emphasised (I will return to the significance of this difference in my conclusion). Rather than simply attempting to act virtuously to ensure a favourable rebirth, the ideal was to escape samsāra altogether by attaining mokșa or release, a state entirely free from the bondage of actions or karma. Since it is action which leads to rebirth, it is hardly surprising that the traditional way to achieve such liberation was thought to be through a renunciatory way of life in which one attempted to give up action altogether by turning one's back on the world. Various forms of 
ascetic practices - solitariness, the mortification of the body, the repression of desires, and the use of meditation techniques - were designed to aid the renouncer in achieving a state of near inaction, in which the world and its objects meant nothing to her, and thus were no longer capable of keeping her enchained.

For Kṛ̣na, however, the idea that one might give up all action in this way is illusory: 'A person does not avoid incurring karman just by not performing acts, nor does he achieve success by giving up acts. For no one lives even for a moment, without doing some act' (BG 3.5: p. 81). Even the bare minimum of bodily subsistence would be impossible without action; one must act therefore simply to stay alive. Accordingly, since it is thus impossible to avoid acting in one way or another, the renouncer's attempts to withdraw completely from the world are futile. Indeed, ascetic practices are no less recognisable as species of activity than those undertaken by someone wishing to engage positively with the world - even abstaining from action is itself an act. Kṛṣna thereby affirms practical action as an inescapable feature of human existence.

If then action cannot be transcended through renunciation, how is one to attain liberation from its karmic consequences in the endless round of birth and rebirth? This is the question to which Kṛṣna's consolation of Arjuna will provide the answer. For in the first instance he sees the latter's refusal to fight effectively as an attempt at renunciation, as indicative of a desire to slough off the prescribed actions and responsibilities relevant to his position as a kșatriya, and therefore as part of a misguided effort to deny the necessity of action itself. More generally, however, Kṛ̦̣na understands Arjuna's reaction to the events at Kurukșetra as symptomatic of a wider cultural malaise affecting the spiritual well-being of its members, and which leads to their endless rebirth. As such, Kṛṣna provides not only a diagnosis of that condition, but its aetiology. And in so doing he paints a vivid portrait of the 
prevailing or currently attained state of the society to which Arjuna has conformed or become fixated, one in which its inhabitants maintain that:

...this world has no true reality, or foundation, or God, and is not produced by the interdependence of causes. By what then? By mere desire. Embracing this view, these lost souls of small enlightenment are with their dreadful actions capable of destroying this world they seek to hurt. Embracing this "desire", which is insatiable, they go about, filled with the intoxication of vanity and selfpride...they are totally immersed in the indulgence of desires, convinced that that is all there is..."This I got today, that craving I still have to satisfy. This much I have as of now, but I'll get more riches. I have already killed that enemy, others still I have to kill. I am a master, I enjoy, I am successful, strong and happy. I am a rich man of high family; who can equal me? I shall sacrifice, I shall make donations, I shall enjoy myself", so they think in the folly of their ignorance. Confused by too many concerns, covered by a net of delusions, addicted to the pleasures of desire, they fall into foul hell. Puffed up by their egos, arrogant, drunk with wealth and pride...Those hateful, cruel, vile, and polluted men I hurl ceaselessly into demonic wombs. Reduced to demonic wombs birth after birth, and deluded, they fail to reach me, Kaunteya [Arjuna], and go the lowest road. (BG 16.8-20: pp. 133-5)

In other words, Kṛ̣na identifies Arjuna's culture as one in which individual self-interest, greed and ambition predominate, where individuals are motivated solely by the satisfaction and fulfilment of their personal goals and desires. As the passage suggests, an individual's desires can and do fluctuate: the pursuit of wealth, for example, may be superseded by a desire for power. Thus, the specific objects or goals which the person concerned aspires to only have significance when, and in so far as, they are desired. 
Furthermore, this suggests that for such individuals the meaning of life itself is determined by the particular array of wants and impulses which it contains, and with which they successively identify. From this perspective, the good (life) for human beings is determined by whatever satisfies the ego's current demands; the good becomes what is good for it. And given the fluctuating and contingent nature of the ego's whims and dispositions, the meaning of life - what it means to flourish as a human being - so construed is only as strong as, and therefore always at the mercy of, the desire which currently gives it significance. In short, the ego itself becomes the standard by which the meaning of life is decided.

Consequently, the existence of any value beyond or other than the (human) will is denied. The world is seen as devoid of truth - understood as something existing independent of the determinations of the ego, as something which may contradict its desires, but which it nonetheless may grasp - and, indeed, any other ideals or goals which go beyond earthly human life. For such a cast of mind, the world is viewed as created solely by human desire or volition, and existing only as a pleasure garden for the senses (BG 3.16: p. 83). For Kṛ̣na, such a view is symptomatic of the ego's maddened desire to believe itself at the centre of all things. In other words, to occupy a position akin to that of God. But as the above passage makes horrifyingly clear, the price which Kṛ̣na exacts for this prideful human craving to assume his place is endless rebirth. Indeed, the idea of rebirth itself can be understood as a further expression of this state of human self-aggrandisement. For in so far as it is governed by the law of karma, the doctrine of rebirth betokens a sense of the universe as keeping score of the moral worth of human actions, and eventually apportioning us recompense and justice for what we have done or failed to do. Thus, once again, the emphasis is on the universe as a place centring on human well-being. 
But what has all this to do with Arjuna? It may well be an accurate description of the present condition of his culture, but it is not obvious that his refusal to fight is motivated by selfish interests. Indeed, he claims that he has no longing for victory, the kingdom, or for things of pleasure if the price he must pay to attain them is to wage war against his family and friends; he would in fact rather himself be slain in the upcoming battle than do so (BG 1.32-46: pp. 71-3). Kṛ̣na, however, sees Arjuna’s concerns regarding the battle as but one manifestation of the general tendency to put the demands of the self centre stage; that, like an explicit desire for wealth or victory, they place an undue stress on the individual's conception of the results or 'fruits' (phala) of her actions as the determining feature of their worth or character. In other words, for Kṛ̣na what is wrong with Arjuna's presently attained state is the degree to which it expresses a trumping of his dharmically prescribed duty to fight by his personal convictions regarding the adverse consequences of prosecuting that duty. Kṛ̣na thus views Arjuna's crisis as indicative of a predilection to style himself as the source of moral judgement, as the determiner of what is right and wrong, of what actions ought and ought not to be done; and thereby to be exhibiting a form of moral arrogance or moralism. And it is this disorientated and disorientating condition from which Kṛ̣ṇa wishes to draw Arjuna, to lead him to decline the attained state of his society, and instead incline towards the one which it neighbours.

\section{Karmayoga and Individuality}

For Kṛ̣na, of course, the means by which Arjuna may be so drawn is by reorienting him towards his dharma. As a kșatriya, dharma dictates that Arjuna (and anyone of the same status) is duty-bound to fight, irrespective of circumstance and whatever the consequences. As Kṛṣna declares baldly: 'Your entitlement is only to the rite [action], not ever at all to its fruits' (BG 2.47: p. 79). 
Accordingly, Kṛ̣na proposes that Arjuna cultivate a form of spiritual discipline or yoga which will enable him to replace his concern or interest in the potential results or consequences of his actions with a species of indifference or disinterest towards them. This is the famous karmayoga (the discipline of action or works) which by its exercise will effectively detach Arjuna from what he does; thereby allowing him to perform actions only because it is his dharma to do so - to act from duty alone rather than any personal motive. As Kṛṣna suggests, 'Holding alike happiness and unhappiness, gain and loss, victory and defeat, yoke yourself to the battle, and so do not incur evil' (BG 2.38: p. 77). It is important to note that in emphasising detachment or indifference with regard to action Kṛ̣na is not thereby advocating a species of carelessness or neglect, as if he were suggesting that one cease completely to consider or care about one's actions. For it must be a feature of acting morally that one perform one's prescribed duties satisfactorily: indeed, doing one's duty may involve a high degree of attention and commitment to the proper enacting of one's appointed tasks. Kṛṣna's point is not that one ought to give up caring about one's actions; but rather that one ought to give up caring about the specific ends or goals of one's action understood as the motivation or point for undertaking them; that one act not for the sake of some particular end or goal, but for the sake of dharma. In this respect, the species of indifference or disinterest which Kṛșna propounds could be said to comprise a state of impartial or unselfish interest rather than a total divestment of interest altogether; although one is not acting in order to satisfy some desire or achieve a particular goal, one's true interests are always dharmic.

It is with this conception of action in accordance with dharma that Krșna reworks the orthodox, Upanișadic understanding of action as that which is necessarily binding to the cycle of birth and rebirth in conformity with the law of karma. As we have seen, for Kṛsna, the traditional strategy to escape the bondage of action by way of asceticism or renunciation is fundamentally flawed; for it mistakenly views action as a disposable, rather than inalienable, 
feature of human existence. However, in so far as he still wishes to maintain the possibility of mokșa or release from samsāra (and thus to a certain degree the traditional doctrine of the karmic effects of action) Kṛ̣na must therefore provide a way to mokșa which acknowledges rather than denies the ineliminability of human activity. The answer is not, like the renouncer, to strive per impossibile to avoid acting altogether - for a state of total inactivity; but rather to perform one's actions in a certain manner or cast of mind - to act disinterestedly, without attachment to one's actions and for the sake of dharma. This karmayoga thus allows Kṛ̣na to steer a course between the Scylla of insatiate desire and the Charybdis of ascetic austerity; to propose what can be thought of as a mode of active passivity in which, by abandoning concern for the fruits of action, one is able effectively to act without acting, thereby expressing an understanding of what Kṛ̣na sees as, the action in inaction and the inaction in action (BG 4.18-20: p. 87). As a result of practising such a yoga, Kṛ̣na proclaims that one is no longer bound by action and the perpetual living out of its karmic effects: 'The enlightened... rid themselves of the fruits that follow upon acts; and, [so are] set free from the bondage of rebirth' (BG 2.51: p. 79). One is thus free to act without incurring or amassing any karmic debt or credit that would necessitate a further round or life in the samsāric cycle. In other words, in terms of karmayoga, acting disinterestedly constitutes a route to mokșa, the end or goal of human existence.

This then is the perfectionist lesson which Kṛṣna gives Arjuna. The respect for and commitment to dharma which karmayoga expresses, is the means by which the latter may overcome the condition of overriding self-interest and aggrandisement which constitutes the presently attained state of his society; and of which his dilemma on the field at Kurukșetra is but one further manifestation. By detaching himself from his actions on the battlefield he gives up the indulgence of personal interest that has provoked his concern with the possible outcome of his actions, replacing it instead with his previously eclipsed commitment to his 
dharma as a kṣatriya, and so to dharma itself. He thus effectively (re-)inhabits - in a way in which he may not have done before - the specific duties and actions which are his to perform and make him who he is. And in overcoming his doubts with respect to dharma - the moral, social and cosmic law - Arjuna thereby regains not only his identity, but his grip on the world which dharma generates and sustains, and in which that identity has a place.

It might seem however that by restoring Arjuna to what is essentially a public or impersonal role as a kșatriya (i.e., an occupation for which he is substitutable by anyone else), Kṛṣna's lesson runs contrary to the basic aims of perfectionist teaching; that rather than seeking to avert his younger friend's conformity to the present arrangement of his culture - in provoking him to refuse its current dispensations - Kṛṣna is in fact reinforcing Arjuna's adherence to that arrangement by provoking his acceptance of those dispensations, and thus repressing, rather than cultivating, his individuality or autonomy. But this is to suppose that individuality consists in the total absence of the determination of social categories, practices and concepts; that one's identity can be defined on a wholly personal rather than cultural basis. However, such an absence would, rather than guarantee one's individuality, lead to the loss of such a possibility altogether (as Arjuna's identity crisis on the eve of battle so vividly illustrates). For in so far as Arjuna inhabits a (heroic) society in which one is what one does, his identity and the issue of its potential individuality are functions of how he responds to the socially defined roles and tasks which are his to perform. Individuality is thus not the denial of sociality but a specific mode of relating to or inhabiting it: the resources which make individuality a possibility, for expressing oneself in an individual way, are ones which are available in principle to all - they are social. In other words, sociality is not simply an obstacle to individuality or autonomy, but the condition for its possibility; the horizon within which such an achievement must be made. 
Consequently, one's capacity for individuality is not absolute; one must always begin from, as well as constantly relate to, the specific array of possibilities which one's culture and society make available - one cannot help but be partially yet deeply determined by the prevailing social, moral and political arrangements of one's culture (and to which one is always at risk of becoming fixated). Given such a condition, conformity is to be diagnosed not by merely identifying the determining effects of social categories or practices; but rather by detecting an adoption of categories and practices which are in some way alien to oneself or one's true nature. In other words, an individual conforms by denying the specific nature of her situation: acting as if she were in a situation other than her own; by, in effect, acting as if she were someone else. And Kṛ̣na explicitly warns Arjuna against precisely such an impersonation: 'One's own Law imperfectly observed is better than another's Law carried out with perfection. As long as one does the work set by nature, he does not incur blame' (BG 18.47: p. 141). Kṛṣna's task to resuscitate Arjuna's autonomy or individuality - to lead him out of conformity - thus becomes one of reawakening him to an awareness of his own identity; to a conscious recognition of the specific duties, practices, responsibilities and relations which constitute his (rather than someone else's) particular position within varnāśramadharma. And in so doing, lead Arjuna to (re)affirm that position by making it genuinely his own - to make the dharma of the ksatriyas his personal duty or svadharma by 'devoting himself to his own task' (BG 18.45: p. 141). If, however, Arjuna had not been brought into crisis by Kṛ̣na as God the opportunity for such an appropriation would have been left unattained. He may well have ridden into battle unhesitatingly, but he would effectively have been blindly following convention rather than dutifully respecting his dharma.

In this way, Kṛṣna’s purpose can be understood as attempting to encourage an internal shift within Arjuna: from an unthinking or unreflective conformism in the way he lives to an 
awakened possession of the specific character of his life. Of course, the idea of the occurrence of an internal shift or transformation within the individual lies at the heart of perfectionism and is directly related to its understanding of human beings as inherently split. And further evidence that the Gitta cleaves to such a conception of the divided or doubled nature of human beings comes to light when Kṛṣna glosses his advice to Arjuna in the following terms:

Let him by himself save himself and not lower himself, for oneself alone is one's friend, oneself alone one's enemy. To him his self is a friend who by himself has conquered himself; but when the man who has not mastered himself is hostile, he acts as his own enemy. (BG 6.5: p. 93)

The confusion in which Arjuna finds himself can thus be understood as the result of an internal conflict; an enmity between two aspects or states of his selfhood. Accordingly, Kṛ̣nạa's attempt to incline him to favour his attainable state of individuality over his presently attained (and despairing) state of conformity can be thought of as an act of friendship that attempts to provoke him into an act of self-befriending (thereby affirming Kṛ̣na as taking on the role of Arjuna's attained self). By detaching himself from his actions and his karma through spiritual discipline, and thus embracing his svadharma, Arjuna is able to attain a mode of self-possession or self-reliance which allows him to overcome his internal antagonism: a state, '[w] hen thought ceases, curbed by the practice of yoga, when he himself looks upon himself and is contented with himself' (BG 6.20: p. 95). In other words, it is a state in which Arjuna now chooses or desires to become who he is - namely, a kșatriya whose dharma it is to pick up his bow Gānḍīva once again and ride on into battle. 


\section{Bhakti}

To anyone familiar with the Git $t \bar{a}$ the above account of the text may seem rather curious, for aside from a few passing remarks it contains little discussion of the issue which forms the most famous and climactic scene of the work - the fact of Kṛ̣na's divine nature as the god Viṣnu which is registered in the work's title and so startlingly revealed to Arjuna in the aweinspiring theophany of chapter 11 . Indeed, it may seem to such a reader that this omission is part of a more general neglect of what they would (quite rightly) understand to be the Gitta's most fundamental concern - namely, religion. Accordingly, I want now to turn to specifically religious matters, and their bearing on the topic of perfectionism. In order to do so, it will be necessary first to examine the way in which Kṛṣna's divine status inflects the main themes of his consolation of Arjuna outlined above, before in my conclusion, investigating the more general question of the relation between perfectionism and religion which the Gittà raises.

As we have seen, in the early part of the Gìtā Kṛ̣ṇa advocates karmayoga as the means by which the immorality of his culture may be overcome, samsāra escaped and dharma restored. However in accordance with his subsequent identification with dharma (as its creator, foundation and, famously, its protector $\left.{ }^{6}\right)$, Kṛṣna gradually introduces a new doctrine - that of bhakti or loving devotion towards God - which comes to dominate his discussion and recasts the earlier discipline in the light of his divine revelation. It is commonly thought that Kṛṣna introduces bhakti alongside karmayoga as an alternative or competing path (mārga) to liberation from the everlasting cycle of birth and rebirth (it is in fact typically held that Kṛ̣na provides three such paths, the third being that of knowledge or jĩnana); however, both Kṛṣna's own remarks on the relative merits of each mārga (BG 6. 46-7: pp. 98-9) and indeed the manner and sequence of their presentation, suggest rather that bhakti represents karmayoga's further or deeper specification - that disinterested activity finds, as it were, its apotheosis in loving devotion to God. Accordingly, at this deeper level of analysis the 
defining characteristics of karmayoga - its spirit of detachment, aspect of passivity, and most fundamentally, its ability to offer an escape from the binding effects of action (karman) and so attain mokșa - are all reinterpreted in terms of their relation to the divine.

The key to this reinterpretation is the concept of sacrifice. For it is by making over one's actions as an offering to God that bhakti, one's loving devotion, is best expressed and liberation found. As Kṛṣna explains:

If one disciplined soul proffers to me with love a leaf, a flower, fruit, or water, I accept this offering of love from him. Whatever you do, or eat, or offer, or give, or mortify, Kaunteya [Arjuna], make it an offering to me, and I shall undo the bonds of karman, the good and evil fruits. (BG 9.26-8: p. 107)

Conceptually, sacrifice is often linked to the notion of thanksgiving; an expression of gratitude for the receiving of some gift or other. In the Git $\bar{a}$, sacrifice is understood as a mode of thanking God for the gift of His creating and sustaining the world and all of its creatures, including oneself. Thus the devotee or bhakta, by sacrificing all her actions to God, acknowledges in her existence its ultimate origin and dependence on God's will. With this in mind, we can now see why, from a religious perspective, the ascetic position is so misguided, and, perhaps more importantly, uncover the root of the condition of egoism affecting Arjuna's society. The problem with the ascetic is that in so far as she renounces her worldly life, she thereby scorns the gift of God's creation and her place within that creation as one of God's creatures, she effectively denies her divinely endowed nature as a human being (as such her self-mortification amounts to an emaciation of God's purposes as they are embodied in her (BG 17.6: p. 135)). As a result, the ascetic rather than drawing closer to the divine through austerity moves further from it; for her renunciation of the world is tantamount to a renunciation of (part of) God. She is therefore no better than those who take the opposite extreme and immerse or completely absorb themselves in earthly pleasures to the extent that 
they no longer acknowledge God as the source of those pleasures (as Kṛṣna puts it, effectively acting as 'but a thief' (BG 3.12: p. 83)). For Kṛṣna, such absorption is characteristic of the general condition of contemporary society, one in which human beings lose themselves in the objects of the senses and the 'fruits' of their actions: where the satisfaction of worldly goals and desires is what gives ultimate meaning to their lives. In short, they express an overwhelming egotistical love for creation itself rather than its Creator.

Acting in a spirit of sacrifice is thus a matter of relating to the world whilst remaining detached from it. The devotee must cultivate a mode of active passivity in which she engages positively in the ordinary array of worldly human activities while resisting the selfish or egotistical temptation to immerse herself in them and so lose sight of their divine origin. Her relation to the objects, goals and desires which comprise her life is therefore one of moderation; where moderation is understood not as an embracing of temperateness, but in a sense more reminiscent of Aristotle's conception of the golden mean - as an appropriate or disciplined response to the circumstances that shuns both excess and deficiency (but which nevertheless sanctions extremes of action and behaviour should the circumstances so demand). As Kṛ̣ṇa explains, his doctrine is:

...neither for him who eats too much or not at all, nor for him who sleeps too much or keeps himself awake, Arjuna. Sorrow-dispelling yoga is his who has curbed his meals and diversions, curbed in his motions in activities, curbed his sleeping and waking. (BG 6.16: p. 95)

The devotee therefore treats the objects and desires of everyday life unlike either the ascetic who assigns them no importance (seeing them as effectively worthless) - or the egoist - who assigns them absolute importance (seeing them as all that is effectively worthwhile). Instead she attaches to such goods a relative value which recognises them as part of God's creation and therefore worthy of love - but ultimately dependent on God, whom she loves absolutely. 
Given Kṛ̣na's identification with dharma (that which orders and sustains the world) another way of looking at this recognition would be to say that in so far as the devotee acts to express her love for God, she acts dharmically. That her acknowledgement both of the array of goods which her life contains and indeed her life itself as part of creation thereby expresses her sense of the world as a providential order, as a system of beings with specific identities or natures which interlock with one another in determinate ways set by God (as Kṛ̣na puts it, the devotee 'sees me in everything and sees everything in me' (BG 6.30: p. 97)). In thus choosing to recognise that order by refusing to allow herself to pervert or otherwise deny it (for example, by relating to the world austerely or indulgently) she effectively enacts God's purposes. And Kṛșna makes it clear that although it was he that created the world and now sustains it, it is the duty of human beings to further his design, to follow his example (as an exemplary perfectionist friend) by maintaining the world's coherent order in human action:

[Y]ou too must act while only looking to what holds together the world. People do whatever the superior man does: people follow what he sets up as the standard. I have no task at all to accomplish in these three worlds [the heaven, earth and lower regions], Pārtha [Arjuna]. I have nothing to obtain that I do not have already. Yet I move in action. If I were not to move in action, untiringly, at all times, Pārtha, people all around will follow my lead. These people would collapse if I did not act; I would be the author of miscegenation; I would assassinate these creatures. The wise, disinterested man should do his acts in the same way as the ignorant do, but only to hold the world together, Bhārata [Arjuna].

(BG 3.20-5: p. 83)

One's love for God is thus expressed by acting dharmically; enacting His will as it is manifest in the providential order for the good of the world. Accordingly, the refinding of one's dharma is simultaneously the refounding of one's relation to God. 
During his discussion of karmayoga, Kṛ̣na identified dharmic action as leading to the Git $\bar{a}$ 's equivalent of salvation. In the light of the present discussion we can now see why: since action in accordance with dharma amounts to action in accordance with divine intention, the devotee who acts in such a way effectively does God's work rather than her own; she works not out of a concern for the dictates of her own will but rather for the will of God. But to deny the demands of the ego is to deny the ego itself. As such, the devotee's sacrificing of her actions to God is a mode of self-sacrifice, an act of ego-annihilating selfabnegation in which she lovingly gives her self up to God by allowing Him to manifest Himself in its place. To love God is thus to be in some way united with Him (an idea attested to by the Sanskrit root 'bhaj' from which bhakti is derived, meaning 'to share or participate in’). As Kṛ̣ṇa confirms, 'I deem the most accomplished man of yoga among all yogins who shares in me in good faith, with his inner self absorbed in me' (BG 6.47: p. 99).

It is this sharing in God which brings salvation. For it expresses the devotee's acknowledgement of the existence of something beyond and greater than the human will. The ego's desires are no longer understood as the ultimate determinant of life's meaning, and its maddened belief in itself as at the centre of all things is thus overcome. A crucial aspect of this belief was of course the doctrine of rebirth; that the universe was somehow keeping a tally of the merit and demerit accrued by one's actions (i.e., one's karma), which would then be used to mete out appropriate compensation for one in the form of the nature of one's subsequent rebirth. Loving God however teaches us that the universe does not centre on human well-being, but on Him. As such, we have no rights to claim against the universe, we are as nothing (indeed must become as nothing) in relation to it. Thus, if we give up our conceit with respect to our place in the universe by truly loving and sharing in God there is no karma and no rebirth. As Kṛ̣ṇa promises, he will rapidly haul the devotee 'from the ocean that is the run-around of deaths', and thereafter allow her to enter into him (BG 12.7: p. 121). 
In other words, loving God constitutes the route to mokșa, the end or goal of human existence.

This then is the final teaching which Kṛṣna gives Arjuna. Bhakti is the true means by which the latter may overcome the general condition of profound self-interest, or effective egomania, affecting the present of his society, and of which his dilemma on the field at Kurukșetra is but one further manifestation. By devotedly sacrificing all his actions to Kṛṣna in a spirit of ego-less non-attachment, he gives up his own needs and concerns to become one with God by doing His will. To do so is for Arjuna to recognise his true dharmic self (rather than his egotistical one), to acknowledge his specific place in God's order as a kșatriya and proceed into battle against the Kauravas - overcoming his state of despair by realising his part in Kṛṣna’s divine plan.

But it is important to note that, despite appearances, this fundamentally passive or necessitarian aspect to Arjuna's predicament does not mean the Gìt $\bar{a}$ thereby absolutely excludes or denies the importance of human freedom, of free will. Indeed, without according a central place to such a phenomenon the Gìtā would make little sense. After all, the primary aim of Kṛṣna's consolation of Arjuna is to persuade - rather than command - the latter to fight. And the means which Kṛṣna employs to undertake such persuasion are rational; he offers reasons which Arjuna can recognise as valid in support of his views. In short, he employs argument. It would therefore be extremely curious if, after arguing for his views in this way, Kṛṣna was fundamentally to deny to Arjuna the freedom to decide whether to continue to refrain from fighting or to proceed into battle. (Although Kṛṣna has by far the larger part, the Gìtā is still a dialogue). From a perfectionist point of view, such a denial would be further to repress - rather than awaken - Arjuna's capacity for self-reliance or autonomy; effectively leading him to substitute conformity or fixation to his attained state with conformity or fixation to Kṛṣna, and so merely exchange one mode of heteronomy for 
another. In the end, as Kṛṣna's closing words register, it is up to Arjuna to choose, to reorient himself and his desires: 'Reflect upon this knowledge I have propounded to you, this mystery of mysteries, in its entirety, and then do as you are pleased to do' (BG 18.63: p.145).

\section{A Concluding Moral}

This account of the religious nature of the relationship between Kṛṣna and Arjuna naturally raises the following question: what is the relation between a perfectionist understanding of spiritual reorientation and a religious account of human redemption, and so between perfectionism and religion themselves?

As I noted earlier, in so far as the Gìtā offers the promise of mokșa from samssāra, and thereby posits a fixed goal or end of one's existence, it distinguishes itself from the picture of the endless or ineradicable journeying between selves found in Cavell's perfectionist model. Cavell himself notes this distinction, seeing it as affirming a fundamental difference between what he sees as religious forms of perfectionism, and those of the specifically secular, Emersonian variety to which he is committed. For him, the religious idea would be that: ...the end of all attainable selves is the absence of self, of partiality. Emerson variously denies this possibility (“Around every circle another can be drawn”, from "Circles"), but it seems that all he is entitled (philosophically) to deny is that such a state can be attained (by a self, whose next attainment is always a self). Presumably a religious perfectionism may find that things can happen otherwise. The idea of the self as on (or lost with respect to) a path, as a direction to a fixed goal, needs its own study. I suppose selflessness may be figured as itself a goal or else as constituted by goallessness. (Cavell, 1990, xxxiv)

In other words, Cavell supposes that unlike his own Emersonian conception of the self as always neighbouring some further attainable, but as yet unattained state of itself - and so of 
the self as endlessly journeying on a path which has no end - a religious perfectionism conceives of the end or goal of the self's journey as the attainment of an absence of self, which itself may be understood as a function of the self's goallessness.

In the present context, it is striking that it is precisely a species of goallessness or disinterest which the Gitta offers as constitutive of liberation from the cycle of rebirth: and moreover, that this goallessness is further portrayed as expressive of a mode of selflessness that the devotee who acts in a spirit of sacrifice is one who finds release from samsāra by entering into God. It would seem therefore that although the Gitta belongs to an entirely different tradition to the explicitly Western one within which Cavell chooses to locate perfectionist thinking, it nonetheless meets quite precisely the criterion which he provides to distinguish between its religious and secular forms or versions.

For Cavell then, perfectionism is primarily a secular enterprise, an aspect of the wider culture of modern Western liberal democracy. ${ }^{7}$ Accordingly, it has at its heart a picture of human beings as capable of transforming or redeeming both themselves and their world by drawing upon purely human resources, and so as ultimately integral and wholly selfsufficient or independent beings. But from the religious perspective of the Gìtā, such a view fundamentally conflicts with its conviction that it is God alone who is capable of redeeming, and so transforming, human beings. Instead, Kṛ̣ṇa’s role as a divine teacher suggests a picture of human beings as inherently inadequate, as essentially reliant upon someone or something radically other than themselves (on supernatural aid); and so as ultimately dependent (I take it that this is what underpins the central emphasis on the theme of passivity which runs through the text).

In this way, the secular aspirations of the perfectionist model appear as a denial of the determining influence of the divine: its emphasis on human self-sufficiency and the central place it accords to self-realisation not only run contrary to the central tenets of the Gittā's 
religious teaching, but appear as symptomatic of the unlawful or adharmic condition of the present age (the Kaliyuga), a further manifestation of the maddened human desire to place the demands of the self centre stage - to put human beings rather than God at the centre of the universe. For the Gìtā, the goal is not to emphasise or underwrite the needs of the self (such as those exemplified by Arjuna's despair on the eve of battle), but ultimately to give them up, to attain a mode of selflessness by entering into Kṛṣna as God.

Recalling my introductory remarks, we might see this as the point at which the Gitta presents an opportunity (due to and despite, my perfectionist orientation towards it) to take an independent or critical perspective, not only on Cavell's perfectionist model (and so my approach to the text in those terms), but also on the tradition and culture of which it is a part (hopefully, partly suggesting the fruitfulness of such an approach in the face of the dominant or prevailing interpretations of the text). With this in mind, I want to conclude my reading by very briefly sketching one last lesson which I think approaching the Gìta from a perfectionist point of view nonetheless serves to illuminate, and which I take to be at work in the Gìtā's closing paragraphs.

In order to appreciate it, I will need to invoke one further (so far unmentioned) feature of perfectionist writing. For Cavell takes it that it is characteristic of such writing that it not only contains an image of a relationship or conversation which has as its goal a species of spiritual transformation, but that it attempts to facilitate precisely such a transformation in its readers; that it attempts to engage in just such a relationship or conversation with its audience - effectively attempting to befriend its readers by attracting them (like the older friend does the younger) to privilege their unattained, but attainable selves, over their presently attained selves. Can we understand this as a burden which the Gìt $\bar{a}$ takes on for itself?

As we have seen, Kṛṣna propounds acting in a spirit of sacrifice as the means by which human beings may be released from their present bondage and come unto God. In his 
final words of the dialogue however he identifies the study of his instruction of Arjuna - in other words, the Gìtā itself - as a mode of sacrifice:

He who commits to memory this our colloquy informed by Law, he will offer up to me a sacrifice of knowledge, so I hold. And he who, filled with belief and trust, listens to it, will be released and attain to the blessed worlds of those who have acted right. (BG 18.70-1: p. 145)

Knowledge of the Gitta is thus presented as providing an occasion for a radical transformation of one's moral and spiritual powers akin to that experienced by Arjuna in the text itself. As the title of the work registers, its words are the song of the Lord, and as such it offers to its audience the possibility of entering into a personal relationship with God by hearing His Word. In this respect, the Gìtā suggests that both the crisis which Arjuna faces and Kṛ̣na's response to it are not simply fictional or historically remote, but rather relevant to the real lives of us, its readers - that God's Word is as accessible now as it was when the text was composed. The Gìtā's final moral is therefore one which invites us to revisit Kṛ̣na's scene of instruction on the field at Kurukșetra, and so asks us to consider whether it is a work relevant to our own (by its lights still adharmic and so Godless) age. But is this an invitation we are inclined to accept $?^{8}$

Notes

1. Sen (2009, p. 23). Sen himself is critical of this interpretation.

2. van Buitenen (1981), hereafter BG. All references to the Git $\bar{a}$ will be given by specifying the chapter and verse numbers, followed by the relevant page in the translation, e.g., (BG 11.18: p. 113). 
3. I am not here failing to appreciate the increased prominence of Virtue ethics in contemporary moral philosophy, rather I am emphasising the degree to which the other two doctrines have held (and continue to hold) a dominant position within the field, particularly with respect to interpretations of the Gìtā.

4. In what follows, I do not mean either to speculate or rely upon the fact of Emerson's deep interest in Eastern thinking in general, and the Gìtā in particular.

5. For Cavell's most sustained accounts of his understanding of perfectionism see his (1990) and (2004).

6. See respectively, BG 4.13: p. 87, 7.6: p. 99, 9.17: p. 107; BG 14.27: p. 129; and BG 4.8: p. 87, 11.18: p. 113.

7. The material in this paragraph and the next is indebted to an analogous discussion in chapter 12 of Mulhall (1994).

8. I would like to thank Stephen Mulhall, Martin Warner, Mikel Burley, Oskari Kuusela, and Gavin Flood for their comments and encouragement with respect to this paper during its (unusually long) gestation. I would like to dedicate this paper to my mother, without whose love and support I could not have pursued my interest in philosophy.

\section{References}

Cavell, Stanley. 1990. Conditions Handsome and Unhandsome: The Constitution of Emersonian Perfectionism. Chicago: University of Chicago Press.

—. 2004. Cities of Words: Pedagogical Letters on a Register of the Moral Life. Cambridge, MA: Harvard University Press.

MacIntyre, Alasdair. 1985. After Virtue: A Study in Moral Theory. 2nd ed. London: Gerald Duckworth \& Co. Ltd. 
Mulhall, Stephen. 1994. Stanley Cavell: Philosophy's Recounting of the Ordinary. Oxford: Oxford University Press.

Sen, Amartya. 2009. The Idea of Justice. London: Penguin.

van Buitenen, J. A. B. 1981. The Bhagavadgītā in the Mahābhārata: Text and Translation. Chicago: University of Chicago Press. 